\title{
Hubungan antara Stres Oksidatif dengan Kadar Hemoglobin pada Penderita Thalassemia /Hbe
}

\section{Correlation between Stres Oxidatif and Hemoglobine Level of Thalassemia /Hbe}

\author{
Moedrik Tamam ${ }^{1}$, Suharyo Hadisaputro ${ }^{2}$, Sutaryo $^{3}$, Iswari Setianingsih ${ }^{4}$, \\ Djokomoeljanto ${ }^{5}$, Ag Soemantri \\ ${ }^{1,6}$ Departemen IImu Kesehatan Anak Fakultas Kedokteran Universitas Diponegoro/Rumah Sakit Umum Pusat Dr. \\ Kariadi Semarang \\ ${ }^{2,5}$ Departemen Ilmu Penyakit Dalam Fakultas Kedokteran Universitas Diponegoro/Rumah Sakit Umum Pusat Dr. Kariadi \\ Semarang \\ ${ }^{3}$ Departemen Ilmu Kesehatan Anak Fakultas Kedokteran Universitas Gajah Mada/Rumah Sakit Umum Pusat Dr. \\ Sardjito Yogyakarta \\ ${ }^{4}$ Lembaga Biologi Molekuler Eijkman Jakarta
}

\begin{abstract}
ABSTRAK
Pemberian transfusi darah kronik pada penderita thalassemia dapat menyebabkan kelebihan kadar besi. Kelebihan kadar besi bebas dalam tubuh akan memacu timbulnya oksidan berupa reactive oxygen species (ROS) yang diukur dalam bentuk malondialdehide (MDA). Peningkatan produksi ROS dapat menyebabkan kerusakan membran sel yang mengandung senyawa lipid termasuk eritrosit. Tujuan penelitian ini adalah untuk menilai hubungan antara kadar MDA serum dengan kadar $\mathrm{Hb}$ penderita thalassemia. Metode penelitian ini adalah penelitian observasional kohort prospective dilaksanakan di UTD PMI Kota Semarang. Selama bulan Januari 2006 sampai dengan Desember 2009 dijumpai 32 penderita thalassemia /HbE. Variabel penelitian kadar Hb dan MDA serum. Pengukuran dilakukan sebelum transfusi ke-1, setelah transfusi ke-1 dan sebelum transfusi ke-2. Analisis statistik menggunakan uji Mann-Whitney, uji Wilcoxon dan uji korelasi Spearman. Rerata umur subjek penelitian adalah 9,5 3,13 tahun, laki-laki adalah 25 orang $(46,9 \%)$ dan perempuan 17 orang $(53,1 \%)$. Status gizi 43,8 \% termasuk gizi kurang. Kadar MDA kelompok Hb sebelum transfusi ke-2 $8 \mathrm{~g} / \mathrm{dL} 2,89 \pm 0,451$ dan kelompok $\mathrm{Hb}>8 \mathrm{~g} / \mathrm{dL} 2,19 \pm 0,792$ ( $p=0,01$ ). Ada korelasi negatif antara Hb sebelum transfusi ke-2 dengan MDA ( $r=\min 0,52 ; p=0,002)$. Dapat disimpulkan ada korelasi negatif antara kadar MDA serum dengan kadar $\mathrm{Hb}$ pada penderita thalassemia $/ \mathrm{HbE}$.
\end{abstract}

Kata Kunci: Hemoglobin, MDA, stres oksidatif, thalassemia / $\mathrm{HbE}$

\begin{abstract}
Chronic transfusion on thalassemia patients may cause excess of body iron. The increase of body iron may stimulate oxidant production such as reactive oxygen species (ROS) that measured as malondialdehyde (MDA). Increase of ROS production cause cell including erythrocyte membrane destruction that contained lipid compound. The purpose of this research is to determine the corelation between serum level of MDA and hemoglobine level of thalassemia/HbE patients. An observational cohort prospective study has been conducted on Blood Transfusion Unit of Semarang City. On the period of January 2006 until December 2009 about 32 patients thalassemia / HbE were recruited. Research variables were hemoglobine level and MDA serum. Measurement were conducted before transfusion I, after transfusion II and before transfusion II. Statistical analysis by using Mann-whitney, Wilcoxon test and Spearman-Rank correlation. Average of age was $9,5 \pm 3,13$ year, sex was 25 boys (46,9\%) and $17 \mathrm{girls}(53,1 \%)$. About $43,8 \%$ was have poor nutritional status. MDA level

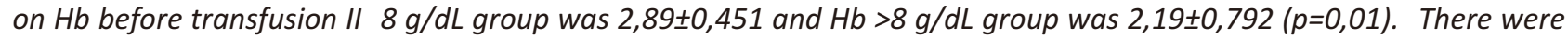
negative correlation between $\mathrm{Hb}$ before transfusion II with MDA ( $r=\min 0,52 ; p=0,002)$. MDA serum was negatively correlated with hemoglobin level of thalassemia/HbE patients.
\end{abstract}

Keywords: Hemoglobin, MDA, oxidative stress, thalassemia / $\mathrm{HbE}$

Jurnal Kedokteran Brawijaya, Vol. 27 No. 1, Februari 2012; Korespondensi: Moedrik Tamam. Rumah Sakit Umum Pusat Dr. Kariadi Semarang, Jl. Dr. Soetomo 16 Semarang Tel. (024)8414296 Email: moedriktamam@yahoo.com 


\section{PENDAHULUAN}

Thalassemia merupakan kelainan genetik yang banyak ditemukan di berbagai bagian dunia termasuk di Indonesia (1,2). Gejala klinis thalassemia bervariasi mulai yang ringan atau thalassemia minor hingga yang berat atau thalassemia mayor. Thalassemia minor umumnya bersifat asimtomatis sedangkan thalassemia mayor membutuhkan transfusi secara reguler untuk mempertahankan hidup penderita. Penderita thalassemia mengalami anemia hemolitik yang terjadi karena umur eritrosit yang memendek oleh karena peningkatan destruksi eritrosit yang terjadi dalam sirkulasi (hemolisis intravaskuler) (3-6).

Pemberian transfusi darah kronik dapat menyebabkan kelebihan besi. Jika kadar besi dalam tubuh berlebihan, peningkatan besi bebas akan memacu timbulnya oksidan berupa reakctive oxygen species (ROS) (7). Oksidan merupakan senyawa yang dapat mengganggu integritas membran sel dan memperberat hemolisis yang terjadi. Peningkatan ROS dalam tubuh akan menimbulkan peroksidasi lipid yang ditandai dengan peningkatan kadar MDA serum. MDA merupakan senyawa yang juga bersifat reaktif. Peningkatan produksi ROS dan MDA dapat menyebabkan kerusakan membran sel yang mengandung senyawa lipid termasuk eritrosit. Peroksidasi membran eritrosit menyebabkan hemolisis sehingga terjadi penurunan kadar $\mathrm{Hb}$ (8). Penelitian ini bertujuan untuk menilai hubungan antara kadar MDA serum dengan kadar $\mathrm{Hb}$ penderita thalassemia.

\section{METODE}

Penelitian ini merupakan penelitian observasional longitudinal prospektif di Unit Transfusi Darah (UTD) Palang Merah Indonesia (PMI) Kota Semarang pada periode Januari 2006 sampai dengan Desember 2009. Subjek penelitian adalah penderita thalassemia yang memperoleh transfusi secara reguler di UTD PMI Kota Semarang. Kriteria subjek penelitian adalah umur 6-14 tahun, tidak mendapatkan terapi hidroksiurea, kadar hemoglobin pasca transfusi $10 \mathrm{gr} / \mathrm{dL}$. Pasien yang mengalami perdarahan, menderita sakit berat dan harus dirawat di rumah sakit, menderita defisiensi G6PD (diperiksa dengan tes reduksi Methylene Blue) atau yang menolak untuk ikut serta dalam peneltian tidak diikutsertakan dalam penelitian.

Besar sampel dihitung dengan rumus besar sampel untuk uji hubungan dengan asumsi koefisien korelasi 0,5 power penelitian $80 \%$, kesalahan tipe I $(\alpha \beta)$ 5\% dan kesalahan tipe II $(\alpha \beta) 20 \%$, maka berdasarkan perhitungan besar sampel diperoleh minimal 29 subjek penelitian. Sampel darah diambil 3 kali yaitu sebelum transfusi pertama, setelah transfusi pertama dan sebelum transfusi kedua.

Kadar Hb diperiksa menggunakan metoda SLS (Sodium Lauryl Sulfate) dari automated hematology analyzer (9). Kadar hemoglobin diperiksa 3 kali yaitu sebelum transfusi pertama, setelah transfusi pertama dan sebelum transfusi kedua. Untuk pemeriksaan MDA, darah vena sebanyak 4 $\mathrm{ml}$ di sentrifugasi pada 3000 RPM selama 20 menit dengan suhu $4^{\circ} \mathrm{C}$. Serum yang terpisah dari sel darah merah selanjutnya digunakan untuk pemeriksaan MDA. Pemeriksaan MDA dilakukan pada hari yang sama dengan pengambilan sampel darah. Apabila pemeriksaan kadar
MDA tidak dapat segera dilakukan, maka sampel serum akan disimpan dalam freezer dengan suhu $-80^{\circ} \mathrm{C}$ di laboratorium GAKI FK UNDIP/RS. Dr. Kariadi Semarang. Pada suhu tersebut tidak akan terjadi perubahan kadar MDA selama 7 hari penyimpanan.

Pemeriksaan MDA mengunakan spektrofotometer berdasarkan perubahan warna akibat reaksi pembentukan kompleks asam thiobarbiturat-MDA. Pemeriksaan spektrofotometri dilakukan pada panjang gelombang 532 $\mathrm{nm}$ (11).

Perbedaan kadar $\mathrm{Hb}$ dan MDA sebelum transfusi pertama dengan setelah transfusi pertama dan sebelum transfusi kedua dianalisis dengan uji non parametric Wilcoxon. Hubungan antara jenis mutasi dengan kategori kadar $\mathrm{Hb}$ dengan kadar MDA serum dianalisis dengan uji korelasi Spearman. Perbedaan kadar MDA antara kelompok dengan kadar $\mathrm{Hb}$ sebelum transfusi ke- $2>8 \mathrm{~g} / \mathrm{dL}$ dengan 8 $\mathrm{g} / \mathrm{dL}$ dianalisis dengan uji non parametrik Mann-Whitney. Nilai p dianggap bermakna apabila $p<0,05$.

Penelitian telah memperoleh Ethical clearance dari Komisi Etik Penelitian Kesehatan FK UNDIP/RSUP Dr. Kariadi Semarang (Ethical Clearance No. 22/EC/FK/RSDK/2005). Kesediaan pasien untuk ikut serta dalam penelitian diberikan dalam bentuk informed consent tertulis. Pasien yang menolak untuk berpartisipasi tetap mendapat pengelolaan sesuai dengan protap pengelolaan thalassemia di UTD PMI Kota Semarang dan RSUP Dr. Kariadi. Seluruh biaya ditanggung oleh peneliti dan subjek telah diberikan imbalan sesuai kemampuan peneliti.

\section{HASIL}

Pada periode penelitian di UTD PMI Kota Semarang dijumpai 80 penderita thalassemia yang mendapatkan transfusi darah secara reguler, namun pada penelitian ini hanya 56 penderita thalassemia $\beta$ mayor yang memenuhi kriteria penelitian. Berdasarkan hasil pemeriksaan PCR diketahui hanya 32 orang subjek yang menderita thalassemia / HbE. Tabel 1 menunjukkan jenis kelamin subjek penelitian sebagian besar adalah perempuan $(53,1 \%)$. Rerata umur subjek penelitian adalah 9,5 tahun dengan usia termuda adalah 4 tahun dan tertua adalah 14 tahun. Berdasarkan kategori LiLA sebagian besar termasuk gizi kurang $(43,8 \%)$.

Tabel 1. Karakteristik subjek penelitian

\begin{tabular}{ll}
\hline Karakteristik & $\mathbf{n}(\%)$ atau Rerata \pm SD; min- $\boldsymbol{m a x}$ \\
\hline Jenis kelamin & \\
$-\quad \quad$ Laki-laki & $15(46,9 \%)$ \\
- Perempuan & $17(53,1 \%))$ \\
Umur (tahun) & $9,5 \pm 3,13 ; 4-14$ \\
Berat badan $(\mathrm{kg})$ & $24,2 \pm 8,17 ; 14,0-43,8$ \\
Tinggi badan (cm) & $126,2 \pm 16,92 ; 96,0-162,0$ \\
Lingkar lengan atas (cm) & $17,1(2,50) ; 13,0-22,0$ \\
Status gizi* & \\
- Gizi buruk & $6(18,8 \%)$ \\
- Gizi kurang & $14(43,8 \%)$ \\
- Gizi baik & $12(37,5 \%)$ \\
Terapi kelasi & \\
- Mendapat & $22(68,8 \%)$ \\
- Tidak mendapat & $10(31,3 \%)$ \\
Kadar feritin serum & $3049,30(452,508) ;(1377,00-3901,80)$ \\
\hline
\end{tabular}

Keterangan:

*Berdasarkan kategori LiLa, ${ }^{5}$ Diukur saat sebelum transfusi 1 
Karakteristik klinis thalassemia ditampilkan pada tabel 2. Pada tabel 2 tampak rerata kadar $\mathrm{Hb}$ sebelum transfusi pertama adalah $10 \mathrm{~g} / \mathrm{dL}$ dan setelah transfusi pertama meningkat menjadi $>10 \mathrm{mg} / \mathrm{dL}$ dan berdasarkan rentang kadar $\mathrm{Hb}$ tidak dijumpai subjek dengan kadar $\mathrm{Hb} 10 \mathrm{~g} / \mathrm{dL}$ setelah transfusi pertama. Sebelum transfusi ke-2 dijumpai 25 orang $(78,1 \%)$ subjek penelitian memiliki kadar $\mathrm{Hb}>8 \mathrm{~g} / \mathrm{dL}$ dan sebanyak 7 orang $(21,9 \%)$ dengan kadar $\mathrm{Hb} 8 \mathrm{~g} / \mathrm{dL}$. Rerata kadar Hb sebelum transfusi ke-2 menurun kembali $10 \mathrm{~g} / \mathrm{dL}$. Hasil uji statistik menunjukkan adanya perbedaan yang bermakna pada perubahan kadar $\mathrm{Hb}$ sebelum transfusi pertama, setelah transfusi pertama dan sebelum transfusi kedua $(p<0,001)$. Hasil uji statistik juga menunjukkan perbedaan antara kadar $\mathrm{Hb}$ sebelum transfusi pertama dan setelah transfusi pertama adalah bermakna $(p<0,001)$, perbedaaan antara kadar $\mathrm{Hb}$ setelah transfusi pertama dengan sebelum transfusi kedua adalah bermakna $(p<0,001)$ dan perbedaan antara kadar $\mathrm{Hb}$ sebelum transfusi pertama dengan sebelum transfusi kedua juga bermakna $(p<0,001)$

Tabel 2. Kadar Hb sebelum transfusi ke-1, setelah transfusi ke-1 dan sebelum transfusi ke-2

\begin{tabular}{lcc}
\hline Kadar Hb $(\mathbf{g} / \mathbf{d L})$ & Rerata \pm SB; Min - maks & $\mathbf{p}$ \\
\hline Sebelum transfusi ke-1 & $7,3 \pm 1,48 ; 4,6-10,6$ & - \\
Setelah transfusi ke-1 & $12,6 \pm 0,35 ; 11,5-13,6$ & $<0,001^{*}$ \\
Sebelum transfusi ke-2 & $8,3 \pm 0,87 ; 5,8-10,5$ & $<0,001^{\S}$
\end{tabular}

*Uji Wilcoxon dibanding kadar $\mathrm{Hb}$ sebelum transfusi ke-1

${ }_{5}^{5}$ Uji Wilcoxon dibanding kadar $\mathrm{Hb}$ setelah transfusi ke-1

Tabel 3 menunjukkan kadar MDA serum setelah transfusi ke-1 menurun dan selanjutnya meningkat kembali sebelum transfusi ke-2. Hasil uji statistik menunjukkan adanya perbedaan yang bemakna pada kadar MDA serum saat sebelum transfusi ke-1, setelah transfusi ke-1 dan sebelum transfusi ke-2 $(p<0,001)$. Pada Tabel 3 juga tampak kadar MDA serum turun secara bermakna dari saat sebelum transfusi ke-1 sampai saat setelah transfusi ke-1 $(p<0,001)$, selanjutnya terjadi peningkatan yang bermakna dari saat setelah transfusi ke-1 sampai sebelum transfusi ke-2 $(p<0.001)$.

Tabel 3. Kadar MDA sebelum transfusi 1, setelah transfusi 1 dan sebelum transfusi 2

\begin{tabular}{lcccc}
\hline Kadar MDA & Rerata & (SB) & Median & p \\
\hline Sebelum transfusi 1 & 1,46 & 0,201 & 1,42 & - \\
Setelah transfusi 1 & 0,92 & 0,376 & 0,97 & $\mathrm{p}<0,001^{*}$ \\
Sebelum transfusi 2 & 2,34 & 0,782 & 2,27 & $\mathrm{p}<0,001^{\S}$ \\
\hline
\end{tabular}

*Uji Wilcoxon dibanding kadar $\mathrm{Hb}$ sebelum transfusi ke-1

${ }^{\S}$ Uji Wilcoxon dibanding kadar $\mathrm{Hb}$ setelah transfusi ke-1

Pada Gambar 1 tampak adanya kecenderungan penurunan kadar $\mathrm{Hb}$ seiring meningkatnya kadar MDA serum. Hasil uji korelasi Spearman menunjukkan adanya korelasi negatif derajat sedang yang bermakna antara kadar $\mathrm{Hb}$ dengan MDA $(r=0,52 ; \mathrm{p}=0,002)$

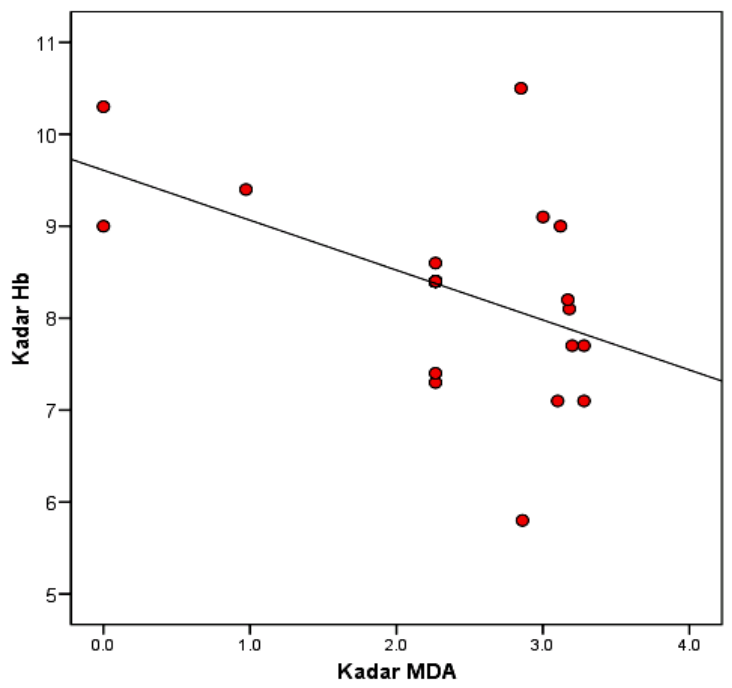

Gambar 1. Korelasi Kadar Hb dan MDA

Pada tabel 4 tampak kadar MDA serum setelah transfusi 1 pada kelompok kadar $\mathrm{Hb} 8 \mathrm{~g} / \mathrm{dL}$ adalah lebih tinggi dibanding kelompok dengan kadar $\mathrm{Hb}>8,0 \mathrm{~g} / \mathrm{dL}$, akan tetapi perbedaan tersebut tidak bermakna $(p<0,5)$. Kadar MDA serum sebelum transfusi ke-2 pada kelompok $\mathrm{Hb} 8$ tampak lebih tinggi secara bermakna dibanding pada kelompok kadar $\mathrm{Hb}>8,0 \mathrm{~g} / \mathrm{dL}(\mathrm{p}<0,001)$.

Tabel 4. Kadar MDA serum sebelum transfusi ke-1, setelah transfusi ke-1 dan setelah transfusi ke-2 berdasarkan kategori $\mathrm{Hb}$ pada saat sebelum transfusi ke-2

\begin{tabular}{|c|c|c|c|}
\hline \multirow[b]{2}{*}{ Kadar MDA } & \multicolumn{2}{|c|}{ Kategori kadar $\mathrm{Hb}$ sebelum transfusi ke-2 } & \multirow[b]{2}{*}{$\mathbf{p}^{*}$} \\
\hline & $\begin{array}{c}\leq 8 \mathrm{~g} / \mathrm{dL} \\
\text { Rerata (SD); Median }\end{array}$ & $\begin{array}{c}>8 \mathrm{~g} / \mathrm{dL} \\
\text { Rerata (SD); Median }\end{array}$ & \\
\hline Sebelum transfusi 1 & $1,49(0,220) ; 1,44$ & $1,45(0,199) ; 1,42$ & 0,2 \\
\hline Setelah transfusi 1 & $0,97(0,455) ; 0,97$ & $0,91(0,361) ; 0,97$ & 0,5 \\
\hline Sebelum transfusi 2 & $2,89(0,451) ; 3,10$ & $2,19(0,792) ; 2,27$ & 0,01 \\
\hline
\end{tabular}

* Uji Mann-Whitney

\section{DISKUSI}

Pada penelitian ini menunjukkan adanya perubahan kadar MDA dari saat sebelum transfusi 1 , lalu menurun setelah transfusi 1 dan meningkat kembali sebelum transfusi ke- 2 . Hasil juga menunjukkan MDA serum sebelum transfusi kedua pada subjek dengan kadar $\mathrm{Hb} 8 / \mathrm{dL}$ adalah lebih tinggi secara bermakna dibanding dengan kadar $\mathrm{Hb}>8$ $\mathrm{g} / \mathrm{dL}$. Kadar Hb juga mempunyai korelasi negatif yang bermakna dengan kadar $\mathrm{Hb}$. Hal ini menunjukkan adanya pengaruh stres oksidatif terhadap kadar $\mathrm{Hb}$ penderita thalassemia/HbE.

Malondialdehid adalah suatu senyawa yang sangat reaktif yang merupakan produk akhir dari peroksidasi lipid, dan biasanya digunakan sebagai biomarker peroksidasi lipid untuk menilai stres oksidatif (10). Peningkatan kadar MDA serum pada penderita thalassemia dapat disebabkan karena adanya timbunan besi bebas dalam plasma. 
Keberadaan besi bebas dalam plasma menyebabkan hidrogen peroksida dioksidasi menjadi ion hidroksil $\left(\mathrm{OH}^{-}\right)$ yang dianggap sebagai sumber utama kerusakan oksidatif. Kelebihan besi akibat tingginya kadar besi plasma dan tingginya kadar besi non haem intrasel pada pasien thalassemia akan menyebabkan meningkatnya generasi ROS dan stres oksidatif (11-13).

Integritas eritrosit dapat terganggu oleh adanya oksidan (terutama gugus hidroksil/OH) yang berasal dari dalam tubuh sendiri, proses peradangan, dari luar tubuh, dan akibat radiasi. Membran sel mengandung asam lemak tak jenuh yang sangat rawan terhadap serangan radikal terutama $\mathrm{OH}$ dan menimbulkan reaksi rantai peroksidasi lipid yang menyebabkan terputusnya rantai asam lemak menjadi berbagai senyawa toksik, antara lain malondialdehida (MDA) yang menyebabkan rusaknya membran sel $(14,15)$.

Rachmilewitz et al, melaporkan eritrosit penderita thalassemia sangat rentan terhadap stres oksidatif. Hal ini disebabkan membran sel eritrosit mengandung lebih banyak lipid dibanding individu normal (11). Penyebab tingginya lipid membran eritrosit penderita thalassemia belum diketahui secara pasti. Ada beberapa kondisi yang diduga berhubungan dengan peningkatan kadar lipid membran eritrosit pada penderita thalassemia yaitu splenektomi dan gangguan fungsi hepar. Cooper et al, melaporkan penderita thalassemia yang mendapatkan splenektomi mempunyai kadar lipid membran eritrosit lebih tinggi dibanding yang tidak splenektomi (16), namun berbeda dengan Cooper, penelitian Rachmilewitz tidak mendapatkan adanya perbedaan yang bermakna pada pada kadar lipid membran eritrosit penderita thalassemia splenektomi maupun tidak mendapatkan splenektomi (11). Gangguan fungsi hepar pada penderita thalassemia dapat terjadi akibat adanya transfusi kronik, namun demikian penelitian Rachmilewitz juga menunjukkan pada pasien thalassemia yang tidak mengalami gangguan fungsi hepar juga dijumpai adanya peningkatan kadar lipid membran eritrosit. Kemungkinan lain adalah adanya polipeptida abnormal akibat adanya cacat molekul globinadalah faktor yang menyebabkan peningkatan lipid

\section{DAFTAR PUSTAKA}

1. Setianingsih I. Molecular Basis of Beta-Thalassemia. Symposium New Horizon in Thalassemia Control from Gene to the Community. Jakarta, 2002; 41-45.

2. Weatherall DJ. The Thalassemias. In: Williams WJ (Ed). Hematology. 4th edition. New York: McGraw-Hill Publishing Co.; 1991; 510-535.

3. Hilman RS and Ault KA. Normal Erythropoiesis. In: Hilman RS (Ed). Hematology in Clinical Practise 3rd edition. New York: Mc Graw Hill Professional; 2005: p. 1-10.

4. Oski FA and Naiman JL. Disorder of Red Cell Metabolism. In: Hematologic Problems in the Newborn 2nd edition. Philadelphia: WB Saunders C; 1972; p. 83-132.

5. Agarwal B and Manglani M. Non Immune Hemolytic Anemia in the Neonate. In: Lokeshwar. Textbook of Neonatal Hematology-Oncology 1st edition. New Delhi: Jaypee Brothers Medical Publisher; 2003; p. 4856. membran eritrosit. Protein integral membran berperan pada fluiditas dan rigiditas membran terhadap oksidasi.

Penelitian Udyaningsih et al mendapatkan adanya perbedaan struktur membran eritrosit penderita thalassemia yang tidak tergantung transfusi dengan yang memerlukan transfusi reguler. Membran sel eritrosit penderita thalassemia yang membutuhkan transfusi khususnya yang telah mendapatkan transfusi jangka lama mudah mengalami kerusakan akibat hilangnya integritas dan fluiditas membran. Protein membran eritrosit penderita thalassemia yang tergantung transfusi memiliki gradasi polaritas membran yang tidak teratur, dalam keadaan normal dijumpai adanya keteraturan degradasi polaritas. Hal ini menyebabkan pita protein ke-3 yang mengandung saluran anion dan air menjadi lebih sensitif terhadap oksidasi, sedangkan protein transport seperti GLUT 1 menjadi meningkat rigiditasnya (17). Desouky et al, melaporkan adanya pergeseran kurva fragilitas eritrosit kearah kadar $\mathrm{NaCl}$ yang lebih rendah pada penderita thalassemia. Selain itu juga dijumpai adanya perubahan sifat membran berupa penurunan konduktivitas listrik. Hal ini menyebabkan hilangnya muatan listrik dan insulasi membran eritrosit sehingga eritrosit mudah mengalami kerusakan apabila terpapar oksidan (18). Selain karena faktor peningkatan stres oksidatif, kerusakan membran eritrosit pada penderita thalassemia juga dapat disebabkan penurunan status antioksidan tubuh. Beberapa jenis antioksidan tubuh antara lain adalah katalase, glutathion peroksidase (GPx), superoxide dismutase (SOD), vitamin C dan vitamin $\mathrm{E}$

Hasil penelitian ini membuktikan adanya pengaruh kadar MDA serum dengan kadar $\mathrm{Hb}$ pada penderita thalassemia. Semakin tinggi kadar MDA semakin rendah kadar $\mathrm{Hb}$ yang mengindikasikan adanya peran stres oksidatif. Pemberian transfusi kedua terbukti dapat memperbaiki kadar $\mathrm{Hb}$ dan menurunkan kadar MDA. Dalam penelitian ini belum dinilai kadar antioksidan dalam tubuh serta asupan vitamin $C$ dan $E$ subjek penelitian sehingga pengaruh antioksidan terhadap stres oksidatif dan kadar $\mathrm{Hb}$ penderita thalassemia / $\mathrm{HbE}$ masih memerlukan penelitian lebih lanjut.

6. Segel GB. Enzymatic Defect. In: Behrman RF (Ed). Nelson Textbook of Pediatrics 17th edition. Philadelphia: WB Saunders Co.; 2004; p. 1488-1491.

7. Laksmitawati DR, Handayani S, UdyaningsihFreisleben SK, et al. Iron Status and Oxidative Stres in B-Thalassemia Patients in Jakarta. BioFactors. 2003; 19(1-2): 53-62

8. Dissayabutra $\mathrm{T}$, Tosukhowong $\mathrm{P}$, and Seksan $\mathrm{P}$. The Benefit of Vitamin $C$ and $E$ in Children with Thalassemia with High Oxidative Stres. Journal of the Medical Association of Thailand. 2005; 88 (Suppl. 4): S317-321.

9. Oshiro I, Takenaka T, and Maeda J. New Method for Hemoglobin Determination by Using Sodium Lauryl Sulfate (SLS). Clinical Biochemistry. 1982; 15(2): 83-88.

10. Janero DR. Malondialdehyde and Thiobarbituric AcidReactivity as Diagnostic Indices of Lipid Peroxidation and Peroxidative Tissue Injury. Free Radical Biology and Medicine. 1990; 9(6): 515-540. 
11. Rachmilewitz E, Weizer-Stern O, Adamsky K, et al. Role of Iron Inducing Oxidative Stres in Thalassemia: Can it be Prevented by Inhibition of Absorption and by Antioxidants? Annals of the New York Academy of Sciences. 2005; 1054: 118-123.

12. Livrea MA, Tesoriere L, Pintaudi AM, et al. Oxidative Stres and Antioxidant Status in Beta Thalassemia Major: Iron Overload and Depletion of Lipid-Soluble Antioxidants. Blood. 1996; 88(9): 3608-3614.

13. Livrea MA, Tesoriere L, D'arpa D, Pintaudi AM, Maggio A, and Pedone E. Oxidative Modification of Low-density Lipoprotein and Atherogenetic Risk in Beta Thalassemia. Blood. 1998; 92(10): 3936-3942.

14. Langseth L. Oxidants, Antioxidants, and Disiase Prevention. Belgium: The International Life Sciences Institute; 1994; p. 1-4.
15. Hilman RS and Ault KA. Hemolytic Anemias. In: Hilman RS (Ed). Hematology in Clinical Practise 3rd edition. New York: McGraw Hill Professional; 2005: 127-142.

16. Cooper RA and Jandl JH. The Role of Membrane Lipids in the Survival of Red Cells in Hereditary Spherocytosis. The Journal of Clinical Investigation. 1969; 48(4): 736744.

17. Udyaningsih-Freisleben SK, Kurniati V, Prasetyo PB, et al. Isolated Erythrocyte Membranes of TransfusionDependent and Non-Transfused Thalassemia Patients in Jakarta, Investigated by Electron Paramagnetic Resonance Spectroscopy. Biofactors. 2003; 19(1-2): 87-100.

18. Desouky OS, Selim NS, El-Bakrawy EM, and ElMarakby SM. Biophysical Characterization of BetaThalassemic Red Blood Cells. Cell Biochemistry and Biophysics. 2009; 55(1): 45-53. 